\title{
Raising achievement levels by means of Suggestopedia M.S. Odendaal
}

\begin{abstract}
The tendency of L2 learners to fossillize at certain language proficiency levels is a phenomenon familiar to all L2 teachers and a source of great frustration for both teachers and learners. In the experiment described in this paper, it appears that a suggestopedic course of \pm 33 hours brought about a meaningful change in the L2 learners' language proficiency. In addition a meaningful improvement in the learners' IQ could be perceived.

$\mathrm{T} 2$ leerlinge se fossilering op 'n bepaalde taalvaardigheidsvlak is 'n bekende verskynsel en die bron van groot frustrasie vir $T 2$ onderwysers. Uit die eksperiment wat in dié artikel beskryf word, blyk dit dat 'n suggestopediese kursus van \pm 33 uur 'n betekenisvolle verandering aan $T 2$ leerlinge se taalvaardigheid gemaak het. Daarbenewens het dit 'n betekenisvolle toename in leerlinge se IK tellings tot gevolg gehad.
\end{abstract}

\section{INTRODUCTION}

Second language teachers' frustration at their inability to raise the level of their learners' proficiency beyond a certain level is a well-known phenomenon. Learners are usually equally discouraged by their slow rate of improvement in fluency, by their inability to think in the second language and by the fossilization of errors in their output.

This has been experienced particularly by English lecturers at teachers' colleges. After 15 years' tuition students still failed to attain the Band 7 that Brendan Carroll considers a prerequisite for a teacher of English as a second language. The fact that most of these students have to teach English in primary schools and would thus perpetuate their own level of proficiency, aggravated the problem. This situation prompted the lecturers in English at the Denneoord College for Continued Training to try Suggestopedia with second language speakers as a means of accelerative learning. An experiment was launched to establish whether the proficiency of second language speakers of English could be improved more rapidly by means of Suggestopedia.

The purpose of this paper is to describe the experiment that was undertaken, to report its findings and to suggest possible implications for education.

\section{AIMS OF THE INVESTIGATION}

The following hypotheses were investigated:

- students' proficiency in English would be raised from an average Band 5/6 to Band 7 on the Carroll scale by means of Suggestopedia;

- students' cognitive skills would be improved;

- students' attitude towards English would be improved.

\section{DESIGN OF THE EXPERIMENT}

\subsection{The target population}

The target population consisted of two groups:

The experimental group which consisted of 15 third year Diploma of Education students of Denneoord College for Continued Training and the control group of 17 third year Diploma of 
Education students of Paarl Teachers' Training College. No students were available at Denneoord to serve as a control group. The two colleges are similar in the following respects:

- both are situated in small, predominantly Afrikaans-speaking towns;

- the medium of instruction in both colleges is Afrikaans;

- both use the same Junior Primary and Senior Primary English syllabuses for colleges of the Cape Education Department;

- the English examinations of both are moderated by the University of Stellenbosch to ensure similar standards;

- both write the same English Bilingualism paper in the final year, which influences the teaching.

The groups can be described as follows:

\begin{tabular}{lll}
\hline & Experimental Group & \multicolumn{1}{c}{ Control Group } \\
\hline Sex & 15 female & $\begin{array}{l}16 \text { female } \\
1 \text { male }\end{array}$ \\
Average age & 21,4 years & 21,05 years \\
MT & Afrikaans & Afrikaans \\
Place of residence & 4 urban & 5 urban \\
& 11 rural & 12 rural \\
Average I.Q. & 108,07 & 109,29 \\
Academic qualifications & matriculation & matriculation \\
Professional training & completing 3rd year of & completing 3rd year of \\
& Junior or Senior Primary & Junior or Senior Primary \\
course at Denneoord & course at Paarl College \\
Coúrse taken & College & Junior Primary 8 \\
& Junior Primary 11 & Senior Primary 9 \\
Average band of pro- & Senior Primary 4 & 6,43 \\
ficiency in English & 6,38 & \\
on Carroll's scale & &
\end{tabular}

The samples could not be selected on a random basis as the two groups have to be together in one institution in order to receive instruction and as there were only fifteen students available at Denneoord College for Continued Education. It will therefore not be claimed that the findings of this experiment have universal significance.

\subsection{Method of instruction}

- The experimental group: Physical relaxation exercises at the beginning of each session.

- Mental relaxation exercises in order to achieve mind-calming and concentration. They were accompanied by soothing music.

- A prelude, or preview, or decoding of the text lasting approximately 10-15 minutes. It preceded the two concerts which were presented approximately every $3 \frac{1}{2}$ hours. It gave the students a preview or "Big Picture" of the subsequent act. Possibly unfamiliar idiomatic language and grammatical constructions were explained to guarantee maximum comprehension and to prevent anxiety. 
- The first concert which lasted approximately 25 minutes, followed the prelude immediately. A chapter of the text was read dramatically and rhythmically to the accompaniment of a Vienna classic concert, e.g. Mozart, Haydn or Beethoven. The students followed the text in copies that had been handed to them just prior to the concert. Full comprehension was obtained by the translations which were provided in the right-hand margin of the text. The students were encouraged to repeat the L2 words and phrases softly to themselves during pauses.

- A brief interval of 2 minutes was allowed subsequently when students could stand up and stretch themselves.

- The second concert lasted \pm 17 minutes. The lights were dimmed, students were encouraged to sit back and relax. To the accompaniment of slow movements from Baroque music, the same text was read with normal phrasing and intonation.

- A period of activation which ranged from $2 \frac{1}{2}$ to $3 \frac{1}{2}$ hours.

Two kinds of activation were used:

primary activations - they were based on the text;

secondary activations which were not direct/directly related to the text, inter alia:

- games to practise the new identities

- developing new biographies, occupations, places of origin

- role play

- games to practise language structures, e.g. snap, dice games

- miming.

The control group: Tuition was given as follows:

Two periods per week ( 70 minutes) were devoted to literature study. Prescribed books were read and discussed in class. Two more periods (70 minutes) per week were devoted to language study. During the fifth period the Senior Primary students received tuition in Didactics.

\section{MEANS OF DATA COLLECTION}

The following tests were administered before instruction commenced and immediately upon completion of the course:

\subsection{Brendan Carroll G.A.D. 1 English Proficiency Test}

The General Advanced Test (copyright Pergamon) was devised by Brendan Carroll for testing communication. It has been standardized and is used in many countries to test communicative competence. In accordance with recent emphases it tests communication (use) rather than the traditionally emphasized formal accuracy (usage) and specific rather than general language skills.

\subsection{Kitching's English Proficiency Test}

This test was developed for Afrikaans-speaking college students, i.e. a target population similar to that of the experimental and control groups. It is being used at Wellington Teachers' College as a placement test for first-years.

\subsection{Dr. H.L. Botha's Opinionnaire}

This attitudinal scale was based on the Rikert Method (Botha: 230). It was developed by Dr. Botha for an M-thesis to determine the attitudes of English-speaking high school pupils towards Afrikaans and the Afrikaans culture. 


\subsection{Nuwe Suid-Afrikaanse Groeptoets for measuring I.Q.}

It was administered by a researcher of the Bureau for Student Counselling of the University of Stellenbosch.

\subsection{Questionnaire on Suggestopedia course}

This questionnaire was devised to record the experimental testees' reactions to the suggestopedic course.

\section{SUMMARY OF THE DATA}

The following tables present the average percentage scores for the pre- and post-tests of the experimental control groups in the different tests:

\subsection{Table 1}

Average percentages of pre- and post-tests of the experimental group for the Kitching Proficiency Test, the Carroll Proficiency Test and the Botha Opinionnaire

\begin{tabular}{llll}
\hline Tests & Pre & Post & Difference \\
KPT & 57,9 & 66,6 & $+8,7$ \\
CPT & 59,4 & 66,13 & $+6,73$ \\
BO & 47,6 & 57 & $+9,4$ \\
\hline
\end{tabular}

5.2 Table 2

$\mathbf{N}=16$

Average percentages of pre- and post-tests of the control group for the Kitching Proficiency Test, the Carroll Proficiency Test and the Botha Opinionnaire

\begin{tabular}{llll}
\hline Tests & Pre & Post & Difference \\
KPT & 56,9 & 58,1 & $+1,2$ \\
CPT & 60,1 & 59,7 & $-0,4$ \\
BO & 46,25 & 47,18 & $+0,93$ \\
\hline
\end{tabular}

5.3 Table 3

$\mathbf{N}=\mathbf{1 4}$

Average I.Q. scores of the pre- and post-tests of the experimental group

\begin{tabular}{llll}
\hline & Pre-test & Post-test & Increase \\
Non-verbal score & 108,92 & 113,5 & $+4,58$ \\
Verbal score & 107,00 & 116,57 & $+9,57$ \\
Total I.Q. score & 108,07 & 116,07 & +8.00 \\
\hline
\end{tabular}

\subsection{Table $4 \quad \mathrm{~N}=16$}

Average I.Q. scores of the pre- and post-tests of the control group

\begin{tabular}{lllll} 
& Pre-test & Post-test & \multicolumn{2}{c}{ Increase/Decrease } \\
Non-verbal score & 109,8 & 110,5 & $+0,7$ & \\
Verbal score & 108,2 & 103,1 & & $-5,1$ \\
Total I.Q. score & 109,3 & 106,9 & $-2,4$ \\
\hline
\end{tabular}


In all the tests the average percentage increase or the increase in average score was higher for the experimental group than for the control group.

\section{SIGNIFICANCE OF AVERAGE SCORE CHANGES}

\subsection{Statistical analysis of data}

The data were submitted to several statistical methods in order to obtain the most refined analysis.

For the: Botha Opionionnaire

Kitching Test

I.Q. test

the t-test for paired comparisons (cf McGhee 1985 pp 374-7) was selected.

\subsection{Analysis of differences between pre-tests of experimental and control groups}

In order to establish whether there was any statistically significant difference between the English proficiency, the I.Q. and attitude of the experimental group and the control group at the commencement of the experiment, viz whether any comparison between the two groups would be valid (or justifiable), the pre-tests of the:

Kitching Test

Carroll Test

I.Q. test

of the control and experimental groups were first compared and subjected to statistical analysis.

The following table presents the results of these analyses.

Table 5

Two sample student $t$-analysis of difference between the experimental $(N=14)$ and control $(N=17)$ groups

$P \quad$ Null hypothesis

\begin{tabular}{llll}
$\begin{array}{l}\text { English proficiency } \\
\text { (Carroll Test) }\end{array}$ & $\mathrm{t}(29)=0,329$ & 0,744 & not rejected \\
$\begin{array}{l}\text { English proficiency } \\
\text { (Kitching Test) }\end{array}$ & $\mathrm{t}(30)=0,322$ & 0,750 & not rejected \\
$\begin{array}{l}\text { Non-Verbal I.Q. } \\
\text { I.Q. test }\end{array}$ & $\mathrm{t}(30)=0,212$ & 0,834 & not rejected \\
\hline
\end{tabular}

\subsubsection{Conclusions}

According to the statistical analysis there was no significant difference between the English proficiency or the I.Q. of the experimental group and that of the control group. In other words both groups were approximately at the same level at the beginning of the experimental period and the degree of difference that could be measured in each at the end of the experiment could therefore validly be compared.

\subsection{Findings}

Subsequently the differences that occurred between the pre-tests and post-tests of the experimental and control groups in the: 
Botha Opinionnaire

Carroll GAD test

Kitching Proficiency Test

Nuwe Suid-Afrikaanse Groeptoets for measuring verbal I.Q.

Nuwe Suid-Afrikaanse Groeptoets for measuring I.Q. total were subjected to t-test analysis.

The following table present the findings of these analysis:

Table 6

Comparison of the t-test analysis of:

\section{Experimental group}

Improvement in positive attitude

towards English

(Botha Opinionnaire)

Improvement in English

proficiency

(Carroll Test)

Improvement in English

proficiency

(Kitching Test)

Improvement in verbal I.Q.

(SA Groeptoets)

Improvement in non-verbal

I.Q.

(SA Groeptoets)

I.Q. improvement in I.Q.

total

(SA Groeptoets) $t(14)=1,374$

$p=0,191$

not significant

$t(14)=4,634$

$\mathrm{p}=0,000$

highly significant

(0,1\% level)

$9(14)=-5,355$

$\mathrm{p}=0,0001$

highly significant

(0,1\% level)

$t(13)=6,051$

$p=0,000$

highly significant

$(0,1 \%$ level $)$

$t(13)=-1,945$

$p=0,037$

significant

at $5 \%$ level

$t(13)=-6,110$
$p=0,000$

highly significant

$(0,1 \%$ level)
Control group

$t(15)=0,222$ $\mathrm{p}=0,827$ not significant

$t(15)=0,330$

$p=0,746$

not significant

$t(16)=0,782$ $p=0,446$ not significant

$t(16)=1,623$

$\mathrm{p}=0,124$

not significant

$$
t(16)=-0,186
$$

$\mathrm{p}=0,854$

not significant

$t(16)=0,789$

$p=0,442$

noi significant

\subsubsection{Conclusions}

Two significant changes were indicated by the test.

- The English proficiency of the experimental group improved significantly during. the period of suggestopedic instruction - from an average band 6,38 to band 7,1 on Brendan Carroll's scale.

- The control group's proficiency showed no significant change, and on Brendan Carroll's scale dropped slightly from an average band 6,43 to band 6,34 .

- The average verbal I.Q. and the I.Q. total of the experimental group increased significantly during the period of suggestopedic instruction, while that of the control group showed no significant change. 


\subsection{Extracts from testees' personal impressions of the course}

\section{Impression}

No. of subjects

One of the most wonderful experiences of my life

Learned without noticing it

For the first time $\mathbf{I}$ could be relaxed in a learning situation

It was marvellous not to have pronunciation and movements restricted 3

$\begin{array}{ll}\text { The atmosphere and the course were enjoyable } & 7\end{array}$

Other subjects should use these methods $\quad 2$

$\begin{array}{ll}\text { Effective and worthwhile } & 2\end{array}$

A great success 4

Was uncertain before when speaking English; gained confidence in using it 6

Increasingly enjoyable to use English 1

Would have adopted English as MT if it had been taught like this $\quad 1$

Vocabulary increased much $\quad 2$

Close ties developed in group $\quad 3$

$\begin{array}{ll}\text { Peripherals aroused interest } & 4\end{array}$

Whole attitude to English changed $\quad 4$

Began to believe I could succeed $\quad 2$

Began thinking in English $\quad 2$

Lost inhibitions 1

$\begin{array}{ll}\text { Enjoyed activities } & 1\end{array}$

$\begin{array}{ll}\text { Was emotionally involved } & 1\end{array}$

Though all the comments were emphatically positive, two students did not contribute their impressions, which may be an indication that they were less positive.

\subsection{Summary of personal impressions}

The main statements made by the questionnaires could be summarised as follows:

- The subjects' response to the course as a whole was strongly positive. Out of a possible 476 responses 21 were negative.

- Great joy was generated during and seemingly by the course. This correlates with the observation and experience of the lecturers.

- The tension during the learning situation was greatly reduced. Subjects were conscious of increased relaxation and loss of inhibitions.

- Subjects' perception of their own command of the target language improved. They said they found they could think in English and one said that when she spoke English "the words just came". This 
impression is supported by the proficiency tests which indicated significant improvement in proficiency. But even without objective support, the subjects' improved confidence in their proficiency would be conducive to acquisition as the affective filter would be lowered.

- Subjects experienced a more positive attitude towards English.

- The group dynamics generated in the group promoted better social relations and three testees commented on the understanding that developed in the group.

\section{CONCLUSIONS}

\subsection{Re-evaluation of hypotheses}

In the light of the data that were collected the hypotheses formulated at the outset of this investigation can be re-evaluated.

\section{HYPOTHESIS ONE}

Students' proficiency would be raised from an average band $5 / 6$ to band 7 on Carroll's scale by means of Suggestopedia.

This hypothesis was sustained. The average band of the students taught by Suggestopedia, band 6,38 on Carroll's scale, was raised to band 7,1 . It was, however, rejected by the students taught by conventional means - their average band 6,43 declined to band 6,34 .

\section{HYPOTHESIS TWO}

Students' cognitive skills will improve significantly as a result of instruction by means of Suggestopedia.

This hypothesis was likewise validated. Students taught by Suggestopedia showed a significant increase in verbal I.Q. and I.Q. total scores. There was no significant change in any of the I.Q. scores of students taught by conventional means.

\section{HYPOTHESIS THREE}

Students' attitude towards English will be improved significantly by means of Suggestopedia.

This hypothesis was not sustained. The attitude of the students taught by means of Suggestopedia did improve more than that of students taught by conventional means but the improvement was significant only at the $20 \%$ level.

\subsection{On the basis of the students' responses (see 6.5) the following conclusions seem valid:}

- Suggestopedia seems able to break through the barrier of fossilizations and it enables students to think in the TL and speak with greater confidence and fluency. The findings of the proficiency tests bear this out.

- Suggestopedia seems to succeed in breaking down the affective filter that impedes language acquisition. Students experience a decrease of tension, an increase in relaxation, an increase in selfconfidence and faith in their performance in the TL.

- Suggestopedia seems to effect personal development. Students experienced enhanced selfconfidence, better relations with their group. (Students' own testimony.)

\section{RECOMMENDATIONS}

In a multi-lingual country such as South Africa

- where so much teaching is done through the medium of a second language 
- where the quality of the teaching is severely affected by the teachers' command of the second language

- where numerous, so far ineffectual, efforts have been made to upgrade the level of the teachers' proficiency in the second language (vide Bot: 1986)

- where underdeveloped cognitive skills seem to retard learning as well as mastery of the medium it seems imperative that a close scrutiny should be directed at a method of language teaching which

- dramatically improves proficiency

- improves cognitive skills.

\section{Bibliography}

BOT, M. 1986. An overview of teacher in-service (SIC) education and training programmes in South Africa. Report commissioned by the Urban Foundation: Indicator.

BEST, J. 1970. Research in Education. New Jersey: Prentice-Hall Inc.

BLAIR. R. (ed) 1982. Innovative Approaches to Language Teaching. Massachusetts: Newbury House Publishers.

BOTHA, H.L. 1981. 'n Ondersoek na besondere faktore wat die verwerwing van Afrikaans as tweede taal by Engelssprekende hoërskoolleerlinge in Kaapland beïnvloed. Unpublished Master's thesis, University of Stellenbosch.

BOTHA, H.L. 1986. Suggestopaedia for second language acquisition. Unpublished.D.Ed. thesis: University of Stellenbosch.

CARROLL, B.J. 1980. Testing communicative performances. Oxford: Pergamon Press Ltd.

DHORITY, L. 1984. Acquisition through Creative Teaching - The Artful use of Suggestion in Foreign Language Instruction. Sharon, Ma: Center for Continuing Development.

LOZANOV, G. 1978. Suggestology and Outlines of Suggestopedy. Translated by Marjorie HallPozharlieva and Pashmakova K. New York, Gordon and Breach.

McGHEE, J.W. 1985. Introductory Statistics. St. Paul. Minnesota: West Publishing Co. 